Entitled Ohne Schusse durch dick und dün, the work is by the man who later founded Windhoek, South West Africa.

\title{
G. K. Hall \& Co., Boston: Research Publications
}

The latest Series Seventy research publications from G. K. Hall \& Co., 70 Lincoln Street, Boston, Massachusetts 021 I 1 , include the following:

Index Libycus: a Bibliography of Libya, 1957-69, with Supplementary Material, 1915-56, compiled by Hans Schluter. Pp. 305. U.S. \$19.50, elsewhere \$21.45.

Catalogue of the C. M. Doke Collection of African Languages, The University of Rhodesia Library. Pp. 546. U.S. \$29.50, elsewhere $\$ 32.45$.

Ghana: an Annotated Bibliography of Academic Theses, 1920-70, in the Commonwealth, the Republic of Ireland and the United States of America, compiled by Joseph Kofi Kafe. Pp. 2 I (estimated). U.S. \$19.50, elsewhere \$21.45.

G. K. Hall have also published Cumulative Bibliography of African Studies, based on the cumulative card index and the quarterly bibliography of the International African Institute: Author Catalogue (2 volumes, c. 59,000 cards), U.S. and British Isles $\$$ i 55.00, elsewhere $\$ 170.50$. Classified Catalogue (3 volumes, $6.76,500$ cards), U.S. and British Isles $\$ 235.00$, elsewhere $\$ 258.50$.

\section{'Cultures et développement' (Université Catholique de Lowain) vol. v, no. 3, 1973 Articles}

Claude Rivière. Les classes en pays sous-developpés. James C. Scott and Benedict J. Kerkvliet. How Traditional Rural Patrons lose Legitimacy (in South-east Asia). John R. Nellis. Three Aspects of the Kenyan Administrative System. Françoise Guibert. Quelques caractéristiques sociologiques de l'IRSAC et du sous-groupement Karibanya (au Zaire).

Comptes Rendus

Ouvrages envoyés à la redaction.

Bibliographie des Sciences du Développement.

\section{Tarifs d'Abonuement}

4 numéros par volume, I volume par an. Belgique: F.B. s00. Étranger: F.B. 550. A payer par virement ou chèque bancaire á la Société Générale de Banque à Leuven (C.C.P. 982), pour le compte No $230-0048$ I 19 -27 de Cultures et développement (Adresse: 62, Tervuurse Vest, 3000 LEUVEN (Belgique), Tél : (OI6) 333.32 ).

\section{'Africa' and 'African Abstracts' on Microfilm}

BACK issues of Africa, volumes I-XLII (1928-72) and African Abstracts, volumes I-XXIII (1950-72) are available on 35-mm microfilm. Further details from: EP Microform Ltd., Bradford Road, East Ardsley, Wakefield, Yorkshire $\mathrm{WF}_{3} 2 \mathrm{JN}$. 